\title{
Study of Some Parameters on the Rate of the Catalyzed Decomposition of Hydrogen Peroxide by $\left[\mathrm{H}_{5} \mathrm{LFe}_{2}(\mathrm{II})\left(\mathrm{SO}_{4}\right)_{2} \cdot \mathrm{H}_{2} \mathrm{O}\right]$ Complex
}

\author{
Magdy A. Wassel ${ }^{1}$, Abdou S. El-Tabl ${ }^{2}$, Ahmed S. Elzaref ${ }^{3}$, Mahmoud M. Arafa ${ }^{4}$, Abdullah A. Alhalib ${ }^{5}$ \\ ${ }^{1,3}$ Chemistry Department, Faculty of Science, Al-Azhar University, Cairo, Nasr city, Egypt \\ ${ }^{2,4,5}$ Chemistry Department, Faculty of Science, Menoufia University, Shebin El-Kom , Egypt
}

\begin{abstract}
Catalytic decomposition of $\mathrm{H}_{2} \mathrm{O}_{2}$ by $\left[\mathrm{H}_{5} \mathrm{LFe}_{2}(\mathrm{II})\left(\mathrm{SO}_{4}\right)_{2} \cdot \mathrm{H}_{2} \mathrm{O}\right]$ complex was studying under different experimental conditions such as different concentration of $\mathrm{H}_{2} \mathrm{O}_{2}(10 \%, 15 \%$ and $20 \%)$, different temperature $\left(25,35\right.$ and $\left.45^{\circ} \mathrm{C}\right)$ and different amounts of complex as a catalyst $(0.1,0.3,0.5$ and $0.7 \mathrm{gm})$. It was observed from the experimental results that the catalytic decomposition rate constant was found to increase by increasing the amount of $\left[\mathrm{H}_{5} \mathrm{LFe}_{2}(\mathrm{II})\left(\mathrm{SO}_{4}\right)_{2} . \mathrm{H}_{2} \mathrm{O}\right]$ complex as a catalyst. This can be explained by higher hydroxyl radicals are farmed in the reaction medium, and also increase in temperature accelerates the Kinetics of catalytic decomposition of $\mathrm{H}_{2} \mathrm{O}_{2}$. Also the thermodynamic parameters: $\left(\mathrm{E}_{a}\right),(\Delta \mathrm{H}),(\Delta G)$ and $(\Delta \mathrm{H})$ were determined.
\end{abstract}

Keywords: Metal complexes, Decomposition, $\mathrm{H}_{2} \mathrm{O}_{2}$, Kinetics, Mechanism

\section{Introduction}

Hydrogen peroxide $\left(\mathrm{H}_{2} \mathrm{O}_{2}\right)$ is involved in all life's vital processes as it is versatile in its uses and applications. Its varied utility ranges from fenton's reagent, bleaching, catalytic activity oxidant for industrial chemical effluents, biological and medical applications. [1]

The kinetics of $\mathrm{H}_{2} \mathrm{O}_{2}$ Catalytic decom-position over [Cu( II) fulvate] complex as a catalyst was investigated. The effect of different concentration of $\mathrm{H}_{2} \mathrm{O}_{2}$, different amount of catalyst and different temperature were studied Based on the rate constants obtained at different temperatures; the empirical Arrhenius expression of $\mathrm{H}_{2} \mathrm{O}_{2}$ decomposition was derived. The reaction was further studied and the values of $(\mathrm{E})$, $(\Delta \mathrm{H}),(\Delta \mathrm{G})$ and $(\Delta \mathrm{S})$ were determined, its well described by an autocatalytic first order equation.[2]

The catalytic decomposition of $\mathrm{H}_{2} \mathrm{O}_{2}$ in pressure of $\mathrm{Fe}_{2} \mathrm{O}_{3}$ $\mathrm{MoO}_{3}$ (2:4) departs from first order kinetics in the sense of an autocatalytic. In the higher stage of $\mathrm{H}_{2} \mathrm{O}_{2}$ decomposition the first order kinetics equation is obeyed.[3],[4]

$\mathrm{H}_{2} \mathrm{O}_{2}$ is widely recommended in aero-space field for propulsive applications for the high energy density and for its "green" nature due to low toxicity and low environmental impact in comparison with conventional propellants $\left(\mathrm{N}_{2} \mathrm{H}_{4}\right.$, $\mathrm{N}_{2} \mathrm{O}_{4}$ ). Nevertheless, the presence of a catalyst is necessary for $\mathrm{H}_{2} \mathrm{O}_{2}$ decomposition due to the low kinetics of the homogeneous reaction. The catalytic activity of innovative materials for the $\mathrm{H}_{2} \mathrm{O}_{2}$ decomposition has been studied under the vaporphase condition at $200^{\circ} \mathrm{C}$, catalysts are based on $\left(\mathrm{MnO}_{\mathrm{x}}\right)$ dispersed on monolithic zirconia substrates. They have been developed using a precipitation technique with an improved procedure, content of the active phase was from 0.5 to $2.0 \mathrm{wt} \%$. Results obtained showed a high activity of the catalyst. The convention was strongly depending on the space velocity and on $\mathrm{MnO}_{\mathrm{x}}$ content on the support. [5]
The catalytic and photocatalytic activities of ramsdellite type manganese oxide, $\mathrm{R}-\mathrm{MnO}_{2}$ were studied from the initial rate of decomposition of $\mathrm{H}_{2} \mathrm{O}_{2}$ in aqueous solution. The kinetic study was followed by the production of $\mathrm{O}_{2}$ via gas pressure monitoring $\left(\mathrm{O}_{2}-\right.$ monitored method) in the dark and under visible light irradiation $(\lambda \geq 400 \mathrm{~nm})$ at $20{ }^{\circ} \mathrm{C}$. Experimental data showed that the rate of $\mathrm{H}_{2} \mathrm{O}_{2}$ decomposition, under visible light irradiation and in the dark, obeys the first order kinetic law. While in the dark the $\mathrm{H}_{2} \mathrm{O}_{2}$ decomposition rate by mass unit was around $6.88 \mathrm{~m} \mathrm{~mol} \mathrm{~g}^{-1} \mathrm{~S}^{-1}$, under visible light in addition the $\mathrm{H}_{2} \mathrm{O}_{2}$ decomposition rate achieved a maximal value of $15.13 \mathrm{~m} \mathrm{~mol} \mathrm{~g}^{-1} \mathrm{~S}^{-1}$. The increase in the $\mathrm{H}_{2} \mathrm{O}_{2}$ decomposition by expect of the visible light was observed in range of catalyst concentration from 16 to 374 $\mathrm{mg} \mathrm{L} \mathrm{L}^{-1}$. These results reflect the potential of $\mathrm{R}-\mathrm{MnO}_{2}$ as photoactive catalyst, being a consequence of pressured photo education of $\mathrm{Mn}^{4+}$ centers. [6]

The decomposition rate of $\mathrm{H}_{2} \mathrm{O}_{2}$ by $\mathrm{Fe}(\mathrm{III})$-nitrilotriacetate complex ( $\left.\mathrm{Fe}^{\mathrm{III}} \mathrm{NTA}\right)$ has been investigated over a large range of experimental conditions: $3<\mathrm{PH}<\mathrm{H},\left[\mathrm{Fe}(\mathrm{III})_{\mathrm{T}, 0}\right.$; 0.05-1 m M ; [NTA $]_{\mathrm{T}, 0} /\left[\mathrm{Fe}(\mathrm{III})_{\mathrm{T}, 0}\right.$, molarratios : 1-250; $\left.\left[\mathrm{H}_{2} \mathrm{O}_{2}\right]_{0}: 1 \mathrm{mM}-4 \mathrm{M}\right)$ and concentration of $\mathrm{OH}$ radicalscavengers : 0-53 $\mathrm{mM}$. Spectrophotometric analyses revealed that reactions of $\mathrm{H}_{2} \mathrm{O}_{2}$ with $\mathrm{Fe}^{\mathrm{III}} \mathrm{NTA}(1 \mathrm{mM})$ at neutral $\mathrm{pH}$ immediately lead to the formation of intermediates (presumably peroxocomplexes of $\mathrm{Fe}^{\mathrm{III}} \mathrm{NTA}$ ) which absorb light in the region $350-600 \mathrm{~nm}$ where Fe ${ }^{\text {III }}$ NTA and $\mathrm{H}_{2} \mathrm{O}_{2}$ were first order with respect to $\mathrm{H}_{2} \mathrm{O}_{2}$ and that the apparent first-order rate constants were found to be proportional to the total concentration of $\mathrm{Fe}^{\mathrm{III}} \mathrm{NTA}$ complexes.

Were at a maximum at $\mathrm{PH}=7.95 \pm 0.10$ and depend on the $[\mathrm{NTA}]_{\mathrm{T}, \mathrm{o}} / \quad[\mathrm{Fe}(\mathrm{III})]_{\mathrm{T}, \mathrm{o}}$ molar natios. The addition of increasing concentration of tert-butanol or sodium bicarbonate significantly decreased the decomposition rate of $\mathrm{H}_{2} \mathrm{O}_{2}$, suggesting the involvement of $\mathrm{HO}^{-}$radicals in the decomposition of $\mathrm{H}_{2} \mathrm{O}_{2}$. The decomposition of $\mathrm{H}_{2} \mathrm{O}_{2}$ by $\mathrm{Fe}^{\mathrm{III}} \mathrm{NTA}$ at neutral $\mathrm{pH}$ was accompanied by a production of

\section{Volume 6 Issue 7, July 2017} www.ijsr.net 


\section{International Journal of Science and Research (IJSR) \\ ISSN (Online): 2319-7064 \\ Index Copernicus Value (2015): 78.96 | Impact Factor (2015): 6.391}

dioxygen and by oxidation of NTA. The degradation of the organic ligand during the course of the reaction led to a progressive dcomplexation of $\mathrm{Fe}^{\mathrm{III}} \mathrm{NTA}$ followed by a subsequent precip-itation of iron (III) oxyhydroxides and by a significant decrease in the catalytic activity of $\mathrm{Fe}(\mathrm{III})$ species for the decomposition of $\mathrm{H}_{2} \mathrm{O}_{2}$. [7]

\section{Experimental}

\section{- Materials and methods}

All chemical were of analytical grade and were employed without further purification. The experimental apparatus as in Fig(1). It contains : (1) sort ball neck (reactor) borosilicate glass $500 \mathrm{ml}$ Volume. (2) A condenser to prevent evaporation of the reaction medium and maintaining constant the content of $\mathrm{H}_{2} \mathrm{O}_{2}$. (3) A heater thermally regulated flask to set the desired temperature (4) Thermometer . (5) A syringes to introduce the oxidant and take sample.

Working solutions of $\mathrm{H}_{2} \mathrm{O}_{2}$ were prepared weekly by volumetric dilution of $30 \%(\mathrm{v} / \mathrm{v}) \mathrm{H}_{2} \mathrm{O}_{2}$ ( $\mathrm{AR}$, grade, Merck ) and were standardized daily by titration with potassium permanganate $\mathrm{KMnO}_{4}$ it was found that the natural decomposition rate of aqueous $\mathrm{H}_{2} \mathrm{O}_{2}$ Solution was less than $1 \%$ in $24 \mathrm{~h}$.

The decomposition of $\mathrm{H}_{2} \mathrm{O}_{2}$ catalyzed by $\left[\mathrm{H}_{5} \mathrm{LFe}_{2}(\mathrm{II})\left(\mathrm{SO}_{4}\right)_{2} \cdot \mathrm{H}_{2} \mathrm{O}\right]$ complex as in $\mathrm{Fig}(2)$ can be kinetically monitored by removing aliquots of the reaction mixture at predeterm9;99999ined intervals and titrating the undecomposed $\mathrm{H}_{2} \mathrm{O}_{2}$ with standard $\mathrm{KMnO}_{4}$ solutions $(0.04$ $0.05 \mathrm{~N})$ standardized with $(\mathrm{COONa})_{2}$ (primary standard). The decomposition of $\mathrm{H}_{2} \mathrm{O}_{2}$ was carried out in a thermostatic cell at different temperatures between 25 and $45^{\circ} \mathrm{C}$.

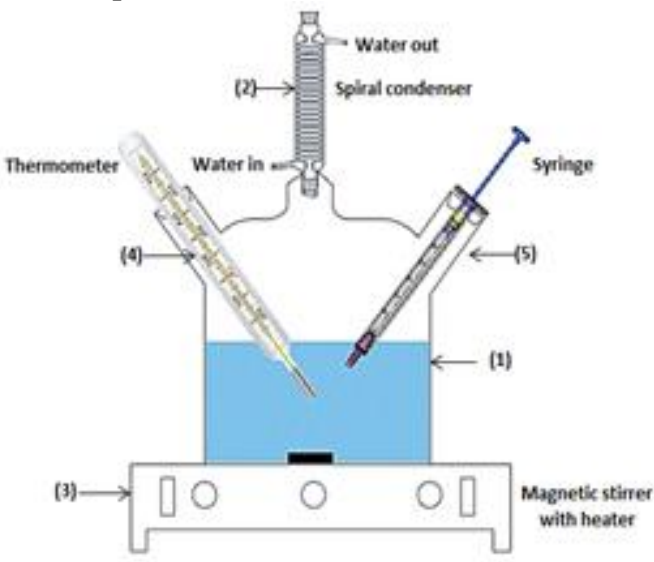

Figure 1: Experimental Apparatus

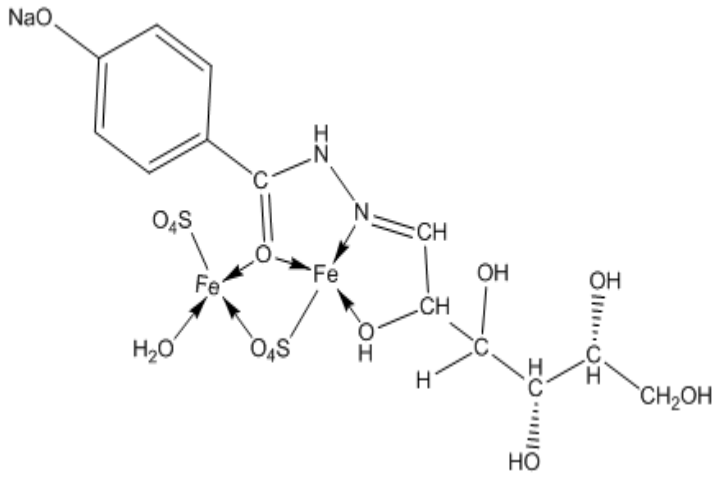

Figure 2

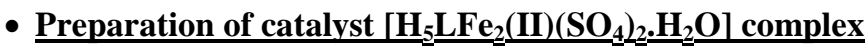

\section{A) Ligand preparation $\left(\mathbf{H}_{s} \underline{L}\right)$}

Sodium salt added to hydrazine by different amount with stirring the suspension at $70{ }^{\circ} \mathrm{C}$ for one hour, The product is filtered and gives a start, starting with glucose with stirring at $60{ }^{\circ} \mathrm{C}$ for an hour and filtered product theLigand as Fig(3).

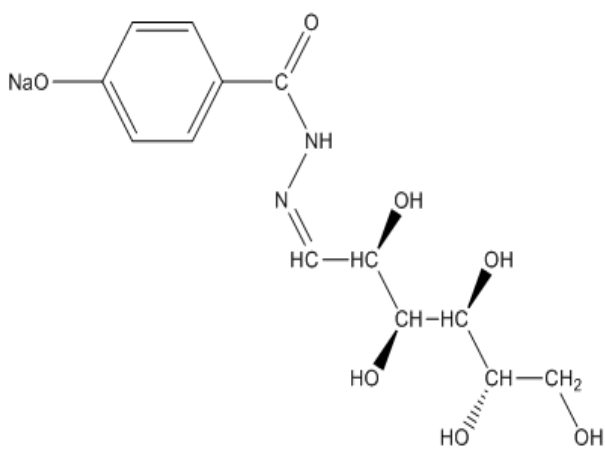

Figure 3

\section{B) Preparation of metal complex $\left(\mathbf{H}_{5} \underline{L}\right)$ :-}

Iron(II)sulphate tetrahydrate dissolved in ethanol warmed at $60{ }^{\circ} \mathrm{C}$ was added to $\mathrm{H}_{5} \mathrm{~L}$ in the same solvent by different amount $(1 \mathrm{~mol})$. The mixture was warmed at $60{ }^{\circ} \mathrm{C}$ with stirring for 1 hour, then the solution was filtered off and dark brown precipitate was obtained by evaporated the solution.Fig(2)

\section{Results and Discussion}

\section{(A) Kinetics of the catalytic decomposition of $\mathrm{H}_{2} \underline{\mathbf{O}_{2}}$ :}

Many experiment were carried out to study the effect of $\mathrm{H}_{2} \mathrm{O}_{2}$ concentration, effect of the amount of catalyst $\left[\mathrm{H}_{5} \mathrm{LFe}_{2}(\mathrm{II})\left(\mathrm{SO}_{4}\right)_{2} \cdot \mathrm{H}_{2} \mathrm{O}\right]$ complex and the effect of different temperature $\left(25-45^{\circ} \mathrm{C}\right)$ on the rate of catalytic decomposition of $\mathrm{H}_{2} \mathrm{O}_{2}$. Although the decomposition of $\mathrm{H}_{2} \mathrm{O}_{2}$ is very complex, it has been shown that under certain operating conditions, the kinetics of decomposition of $\mathrm{H}_{2} \mathrm{O}_{2}$ can be described by a kinetic of pseudo-first order as described in the following the equation(1)

$$
d\left[\mathrm{H}_{2} \mathrm{O}_{2}\right] / d t=-k_{\text {apexp }}\left[\mathrm{H}_{2} \mathrm{O}_{2}\right]
$$

Where $\left(\boldsymbol{k}_{\text {apexp }}\right)$ : the apparent rate constant of the first order, $(t)$ : reaction time and $\left[\mathrm{H}_{2} \mathrm{O}_{2}\right]$ : the concentration of hydrogen 


\section{International Journal of Science and Research (IJSR) \\ ISSN (Online): 2319-7064}

Index Copernicus Value (2015): 78.96 | Impact Factor (2015): 6.391

peroxide at time $(t)$. After integration we obtain the equation(2)

$$
\ln \left(\left[\mathrm{H}_{2} \mathrm{O}_{2}\right]_{o} /\left[\mathrm{H}_{2} \mathrm{O}_{2}\right]\right)=k_{\text {apexp. }} .
$$

where $\left[\mathrm{H}_{2} \mathrm{O}_{2}\right]_{o}$ : initial concentration of hydrogen peroxide.[8]

Kinetic studies in the conditions men-tioned above showed that the initial rate of the decomposition of $\mathrm{H}_{2} \mathrm{O}_{2}$ is proportional to the concentration of hydrogen peroxide and the amount of catalyst $\left[\mathrm{H}_{5} \mathrm{LFe}_{2}(\mathrm{II})\left(\mathrm{SO}_{4}\right)_{2} \cdot \mathrm{H}_{2} \mathrm{O}\right]$ complex as a catalyst and the proposed mechanism of this reaction may be as the following:

$$
\begin{gathered}
V_{o}=-d\left[\mathrm{H}_{2} \mathrm{O}_{2}\right] / d t= \\
k_{d e c}\left[\left[\mathrm{H}_{5} \mathrm{LFe}_{2}(\mathrm{II})\left(\mathrm{SO}_{4}\right)_{2} \cdot \mathrm{H}_{2} \mathrm{O}\right] \text { Complex }\right]\left[\mathrm{H}_{2} \mathrm{O}_{2}\right]
\end{gathered}
$$

\section{Studies the different factors effecting in the Catalytic Decomposition of $\mathrm{H}_{2} \mathrm{O}_{2}$}

\section{1-Study the effect of temperature}

The experiments were performed with $10 \% \mathrm{H}_{2} \mathrm{O}_{2}$ and $0.3 \mathrm{~g}$ $\left[\mathrm{H}_{5} \mathrm{LFe}_{2}(\mathrm{II})\left(\mathrm{SO}_{4}\right)_{2} \cdot \mathrm{H}_{2} \mathrm{O}\right]$ complex. Temperatures of our experimental are carried out between 25 to $45 \mathrm{C}$. As can be seen, the increase in temperature accelerates the kinetics of decomposition of hydrogen peroxide. Indeed, at $45{ }^{\circ} \mathrm{C}$ the decomposition is slow. The rate constants of $\mathrm{H}_{2} \mathrm{O}_{2}$ decomposition as a function of temperatures are given in (Table 1)

\begin{tabular}{|c|c|c|c|c|c|c|c|}
\hline \multirow[b]{2}{*}{ Temp. } & & ime ( $\mathrm{n}$ & & & \multirow{3}{*}{$\mathrm{k}$} & \multirow{3}{*}{ Log $k$} & \multirow{3}{*}{$1 / \mathrm{T}$} \\
\hline & 10 & 20 & 30 & 40 & & & \\
\hline & \multicolumn{4}{|c|}{$\mathrm{Ln}\left(\mathrm{H}_{3} \mathrm{O}_{-} \mathrm{I}_{\text {a. }}\right.$} & & & \\
\hline $25 \mathrm{c}^{\circ}$ & 2.166 & 2.194 & 2.200 & 2.240 & 0.0228 & -2.638 & 0.00335 \\
\hline $35 \mathrm{C}^{\circ}$ & 2.180 & 2.200 & 2.220 & 2.230 & 0.0017 & -2.769 & 0.00324 \\
\hline $45 \mathrm{C}^{\circ}$ & 2.240 & 2.270 & 2.280 & 2.287 & 0.0015 & -2.823 & 0.00314 \\
\hline
\end{tabular}
and (Figure 4-11).

Table 1: Rate constant at different temperature

When we draw $\left(\ln \left(\left[\mathrm{H}_{2} \mathrm{O}_{2}\right]_{\text {dec }}\right)\right.$ versus time $(t)$ at constant temperature 25,35 and $45^{\circ} \mathrm{C}$ as shown in Figure (4, 5 and 6) its clear straight line :

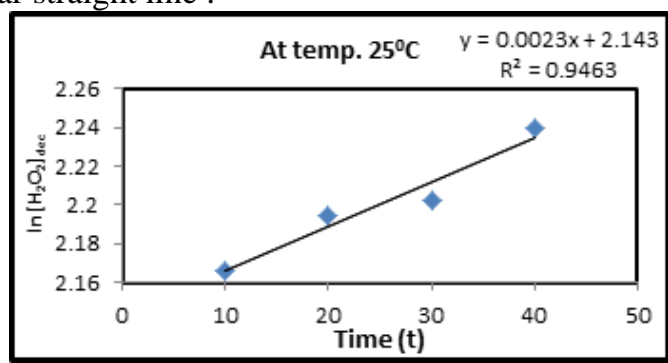

Figure 4: The rate constants of $\mathrm{H}_{2} \mathrm{O}_{2}$ decomposition temperature $25^{\circ} \mathrm{C}$

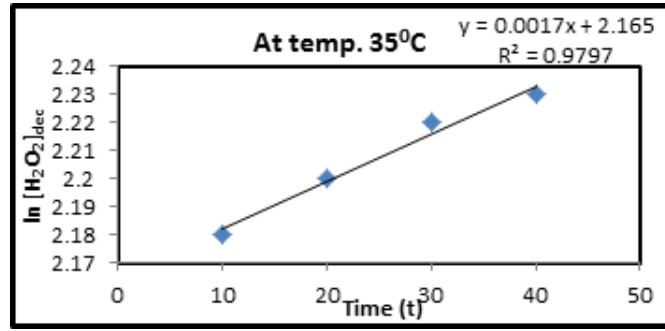

Figure 5: The rate constants of $\mathrm{H}_{2} \mathrm{O}_{2}$ decomposition temperature $35^{\circ} \mathrm{C}$

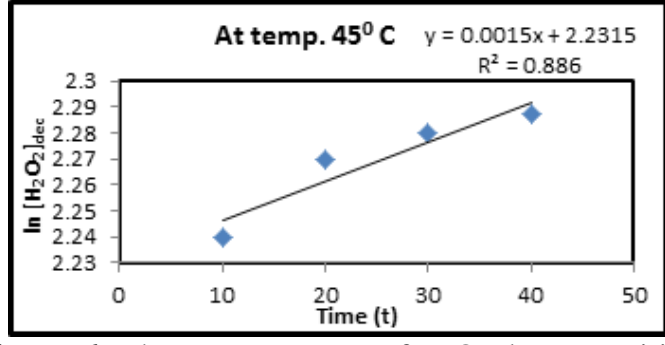

Figure 6: The rate constants of $\mathrm{H}_{2} \mathrm{O}_{2}$ decomposition temperature $45^{\circ} \mathrm{C}$.

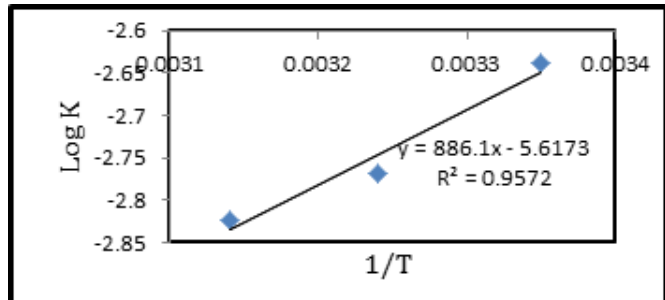

Figure 7: Plot of $\log (k) \mathrm{Vs}(1 / T)$ for the decomposition of $\mathrm{H}_{2} \mathrm{O}_{2}$ by $\left[\mathrm{H}_{5} \mathrm{LFe}_{2}(\mathrm{II})\left(\mathrm{SO}_{4}\right)_{2} \cdot 2 \mathrm{H}_{2} \mathrm{O}\right]$ Complex ; $\left[\mathrm{H}_{2} \mathrm{O}_{2}\right]_{0}=$ $10 \%$

The activation energies of the catalytic decomposition of $\mathrm{H}_{2} \mathrm{O}_{2}$ at temperature range $25-45 \mathrm{C}^{0}$ are calculated from Arrhenius plots and the values obtained are given in Fig (7). It seems that the activation energy $\left(E_{a}\right)$ evaluated from $(k)$ values, $\left(E_{a}\right)$ indicating that the decompositionof $\mathrm{H}_{2} \mathrm{O}_{2}$, we see that Arrhenius equations:

$$
\log k=-E_{a} / 2.303 R T+\log A
$$

Given with slope equal to (- $\left.\mathrm{E}_{\mathrm{a}} / 2.303 \mathrm{R}\right)$ and intercept equal to $(\log A)$. This result are illustrated in Fig (7).

\section{2- Study the Thermodynamic Parameters for the} Catalytic Decomposition of $\mathrm{H}_{2} \underline{\mathrm{O}}_{2}$

The thermodynamic parameters $\left(E_{a}\right),(\Delta H),(\Delta G)$ and $(\Delta S)$ were also determined and illustrated in Table (2). The automatically first order plots derived from following equation:

$$
\log k / T=\log k_{B} / h+\Delta S / R-\Delta H / R T
$$

Here, $(k)$ is the rate constant for the reaction, $(\mathrm{T})$ is absolute temperature, $\left(k_{B}\right)$ is Boltzmann's constant, $(h)$ is Planck's constant, $(\triangle S)$ and $(\Delta H)$ are activation entropy and enthalpy , respectively. The slope of the line obtained using this equations proportional to the activation enthalpy, while the activation entropy can be extracted from the intercept. By performing each reaction at a series off our temperatures and using the empirical rate law to determine the rate constant at each temperature, activation entropy and enthalpy can be calculated. Are illustrated in Fig. (8).and equation (12):

$$
\Delta G=\Delta H-T \Delta S
$$

\begin{tabular}{|c|c|c|c|c|}
\hline $\begin{array}{c}\text { Temp. } \\
\left(K^{\delta}\right)\end{array}$ & $\begin{array}{c}\Delta G \\
(\mathrm{KJ} / \mathrm{mol})\end{array}$ & $\begin{array}{c}\Delta S \\
(\mathrm{~J} / \mathrm{moll} k)\end{array}$ & $\begin{array}{c}\Delta H \\
(\mathrm{KJ} / \mathrm{mol})\end{array}$ & $\begin{array}{c}E_{t} \\
(\mathrm{KJ} / \mathrm{mol}\end{array}$ \\
\hline 298 & -14.54 & \multirow{3}{*}{15.74} & \multirow{3}{*}{19.23} & \\
\hline 308 & -1438 & & & 1696 \\
\hline 318 & -1422 & & & \\
\hline
\end{tabular}

Table 2: Thermodynamic parameter for decomposition of hydrogen peroxide by $\left[\mathrm{H}_{5} \mathrm{LFe}_{2}(\mathrm{II})\left(\mathrm{SO}_{4}\right)_{2} \cdot \mathrm{H}_{2} \mathrm{O}\right]$ Complex as a catalyst 


\section{International Journal of Science and Research (IJSR) \\ ISSN (Online): 2319-7064}

Index Copernicus Value (2015): 78.96 | Impact Factor (2015): 6.391

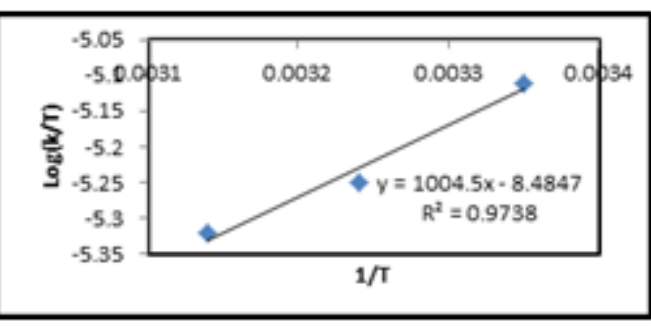

Figure 8: Plot of $\log (k / T)$ vs $(1 / T)$ for the decomposition of $\mathrm{H}_{2} \mathrm{O}_{2}$ by $\left[\mathrm{H}_{5} \mathrm{LFe}_{2}(\mathrm{II})\left(\mathrm{SO}_{4}\right)_{2} \cdot \mathrm{H}_{2} \mathrm{O}\right]$ Complex ; $\left[\mathrm{H}_{2} \mathrm{O}_{2}\right]_{0}=10 \%$

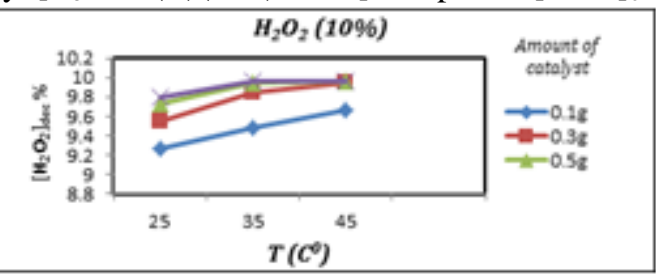

Figure (9): Effect of temperature on the catalytic decomposition of $\mathrm{H}_{2} \mathrm{O}_{2}$ (at $\left[\mathrm{H}_{2} \mathrm{O}_{2}\right]_{\mathrm{o}}=10 \%$, various amount of $\left[\mathrm{H}_{5} \mathrm{LFe}_{2}(\mathrm{II})\left(\mathrm{SO}_{4}\right)_{2} . \mathrm{H}_{2} \mathrm{O}\right]$ complex as a catalyst).

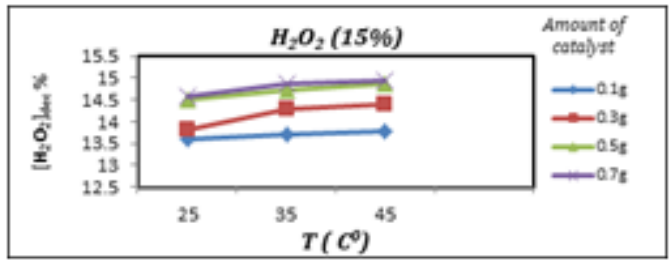

Figure 10: Effect of temperature on the catalytic decomposition of $\mathrm{H}_{2} \mathrm{O}_{2}$ (at $\left[\mathrm{H}_{2} \mathrm{O}_{2}\right]_{\mathrm{o}}=15 \%$, various amount of

$\left[\mathrm{H}_{5} \mathrm{LFe}_{2}(\mathrm{II})\left(\mathrm{SO}_{4}\right)_{2} \cdot \mathrm{H}_{2} \mathrm{O}\right]$ complex as a catalyst)

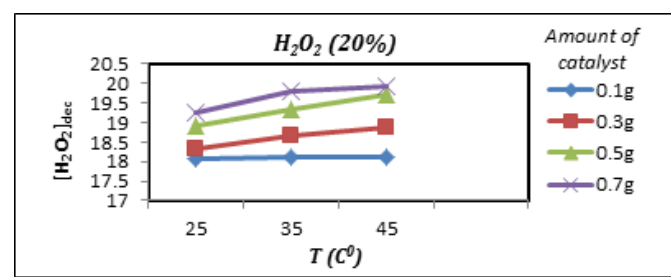

Figure 11: Effect of temperature on the catalytic decomposition of $\mathrm{H}_{2} \mathrm{O}_{2}$ (at $\left[\mathrm{H}_{2} \mathrm{O}_{2}\right]_{\mathrm{o}}=20 \%$, various amount of $\left[\mathrm{H}_{5} \mathrm{LFe}_{2}(\mathrm{II})\left(\mathrm{SO}_{4}\right)_{2} \cdot \mathrm{H}_{2} \mathrm{O}\right]$ complex as a catalyst)

The heterogeneous as catalytic decom-position of $\mathrm{H}_{2} \mathrm{O}_{2}$ over $\mathrm{Fe}_{2} \mathrm{O}_{3}-\mathrm{MoO}_{3}(2: 4)$ is characterized by the presence of an induction period during which the active centers $\left(\mathrm{Mo}^{5+}\right)$ are being formed at the start of reaction [9]in all cases studied an induction period has been encountered before the reaction assumes a significant rate. These results showed also that the induction period $\left(t_{\text {ind }}\right)$ is largely by the amount of catalyst and the temperature of the reaction.

\section{3- Study The effect of the amount of}

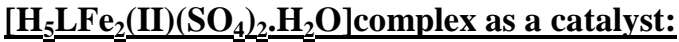

The level of concentrations of $\left[\mathrm{H}_{5} \mathrm{LFe}_{2}(\mathrm{II})\left(\mathrm{SO}_{4}\right)_{2} \cdot \mathrm{H}_{2} \mathrm{O}\right]$ complex used in this study is $(0.1,0.3,0.5$ and $0.7 \mathrm{~g}) \mathrm{A}$ significant increase in the rate of decomposition was observed by increasing the dose of $\left[\mathrm{H}_{5} \mathrm{LFe}_{2}(\mathrm{II})\left(\mathrm{SO}_{4}\right)_{2} \cdot \mathrm{H}_{2} \mathrm{O}\right]$ complex. For high concentrations of $\left[\mathrm{H}_{5} \mathrm{LFe}_{2}(\mathrm{II})\left(\mathrm{SO}_{4}\right)_{2} \cdot \mathrm{H}_{2} \mathrm{O}\right]$ complex, the kinetics of decomposition of $\mathrm{H}_{2} \mathrm{O}_{2}$ is fast. This can be explained by the fact that the higher the $\left[\mathrm{H}_{5} \mathrm{LFe}_{2}(\mathrm{II})\left(\mathrm{SO}_{4}\right)_{2} \cdot \mathrm{H}_{2} \mathrm{O}\right]$ complex, the higher $\mathrm{OH}^{-}$hydroxyl radicals are formed in the reaction medium. The relationship between the amount of catalyst and the catalytic decomposition of $\mathrm{H}_{2} \mathrm{O}_{2}$ at different temperature were illustrated in Fig (12-14).

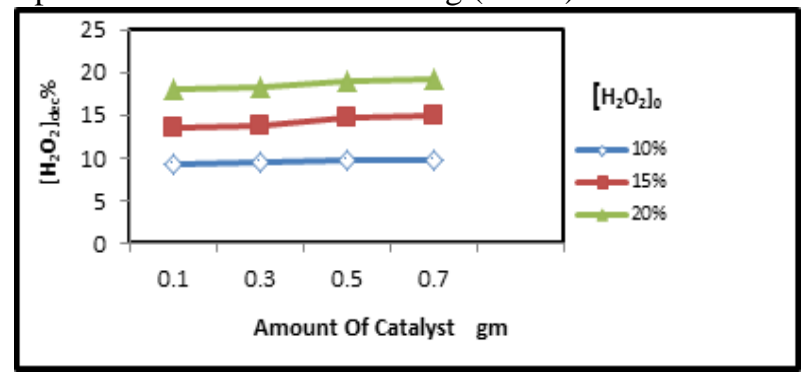

Figure 12: Effect of the amount of

$\left[\mathrm{H}_{5} \mathrm{LFe}_{2}(\mathrm{II})\left(\mathrm{SO}_{4}\right)_{2} \cdot \mathrm{H}_{2} \mathrm{O}\right]$ Complex on the catalytic decomposition of $\mathrm{H}_{2} \mathrm{O}_{2}$ (At various initial concentration of $\mathrm{H}_{2} \mathrm{O}_{2}$, at $25^{\circ} \mathrm{C}$ ).

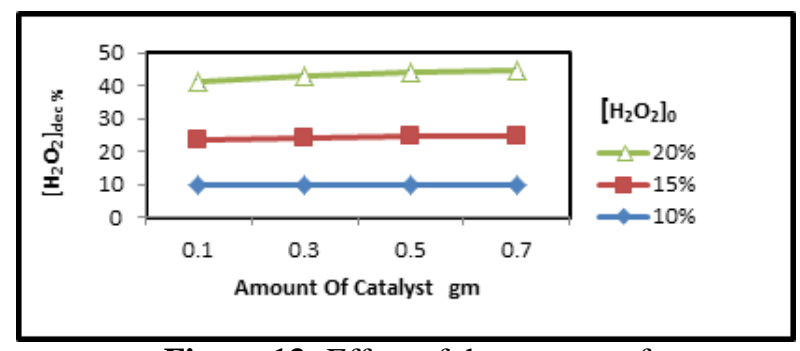

Figure 13: Effect of the amount of

$\left[\mathrm{H}_{5} \mathrm{LFe}_{2}(\mathrm{II})\left(\mathrm{SO}_{4}\right)_{2} \cdot \mathrm{H}_{2} \mathrm{O}\right]$ complex on the catalytic decomposition of $\mathrm{H}_{2} \mathrm{O}_{2}$ (at various initial concentration of $\mathrm{H}_{2} \mathrm{O}_{2}$, at $\left.35{ }^{\circ} \mathrm{C}\right)$

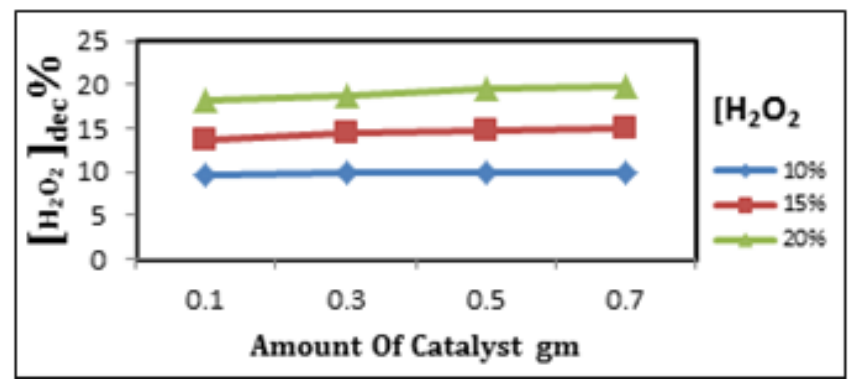

Figure 14: Effect of the amount of $\left[\mathrm{H}_{5} \mathrm{LFe}_{2}(\mathrm{II})\left(\mathrm{SO}_{4}\right)_{2} \cdot \mathrm{H}_{2} \mathrm{O}\right]$ complex on the catalytic decomposition of $\mathrm{H}_{2} \mathrm{O}_{2}$ (at various initial concentration of $\mathrm{H}_{2} \mathrm{O}_{2}, 45^{\circ} \mathrm{C}$ ).

\section{4- Study the Role of $\mathrm{H}_{2} \mathrm{O}_{2}$ Concentration}

In this case, the concentration of $\left[\mathrm{H}_{5} \mathrm{LFe}_{2}(\mathrm{II})\left(\mathrm{SO}_{4}\right)_{2} .2 \mathrm{H}_{2} \mathrm{O}\right]$ Complex is set equal to $0.1,0.3,0.5$ and $0.7 \mathrm{~g}$ respectively, the temperature is varied between $\left(25,35\right.$, and $\left.45^{\circ} \mathrm{C}\right)$ and the initial concentration of hydrogen peroxide is variable from $(10,15$, and $20 \%)$. The evolution of the $\mathrm{H}_{2} \mathrm{O}_{2}$ concentration is reported in Figure (15-18).

As the figure shows the decomposition rate increased by increasing $\mathrm{H}_{2} \mathrm{O}_{2}$ conc-entration. This may be due to the competition between the $\left(\mathrm{OH}^{-}\right)$radicals and other compounds. For high concentrations of $\mathrm{H}_{2} \mathrm{O}_{2}$ the kinetics of decomposition of hydrogen peroxide is fast. This is explained by the Fenton reaction to high concentrations of $\mathrm{H}_{2} \mathrm{O}_{2}$.

\section{Volume 6 Issue 7, July 2017 www.ijsr.net}




\section{International Journal of Science and Research (IJSR) \\ ISSN (Online): 2319-7064}

Index Copernicus Value (2015): 78.96 | Impact Factor (2015): 6.391

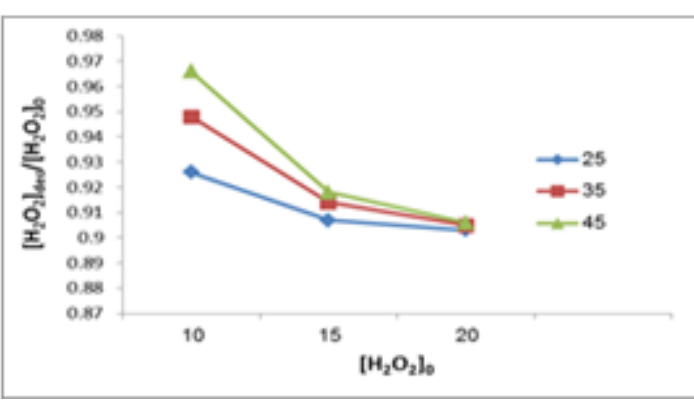

Figure 15: Effect of initial concentration of $\mathrm{H}_{2} \mathrm{O}_{2}$ on the catalytic decomposition of hydrogen peroxide by $0.1 \mathrm{~g}$

$\left[\mathrm{H}_{5} \mathrm{LFe}_{2}(\mathrm{II})\left(\mathrm{SO}_{4}\right)_{2} \cdot \mathrm{H}_{2} \mathrm{O}\right]$ Complex as a catalyst $)$

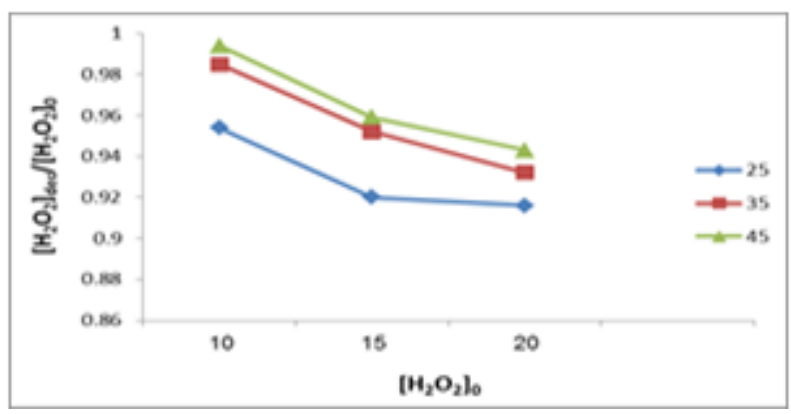

Figure 16: Effect of initial concentration of $\mathrm{H}_{2} \mathrm{O}_{2}$ on the catalytic decomposition of hydrogen peroxide by $0.3 \mathrm{~g}$

$\left[\mathrm{H}_{5} \mathrm{LFe}_{2}(\mathrm{II})\left(\mathrm{SO}_{4}\right)_{2} \cdot \mathrm{H}_{2} \mathrm{O}\right]$ Complex as a catalyst $)$

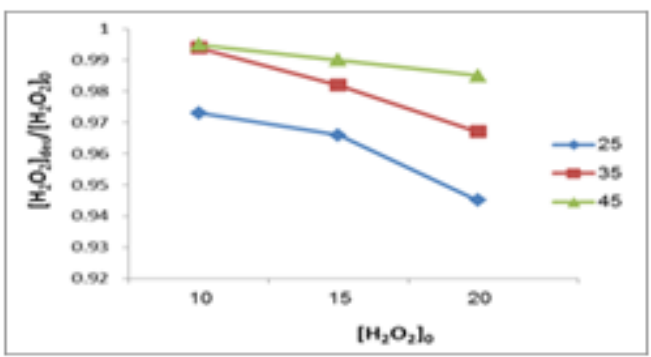

Figure 17: Effect of initial concentration of $\mathrm{H}_{2} \mathrm{O}_{2}$ on the catalytic decomposition of hydrogen peroxide by $0.5 \mathrm{~g}$ $\left[\mathrm{H}_{5} \mathrm{LFe}_{2}(\mathrm{II})\left(\mathrm{SO}_{4}\right)_{2} \cdot \mathrm{H}_{2} \mathrm{O}\right]$ Complex as a catalyst $)$

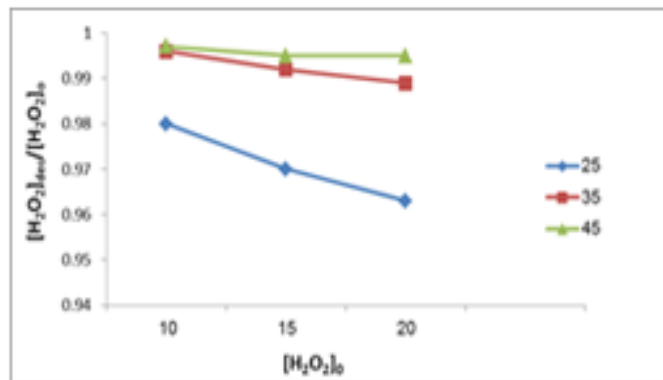

Figure (18): Effect of initial concentration of $\mathrm{H}_{2} \mathrm{O}_{2}$ on the catalytic decomposition of hydrogen peroxide by $0.7 \mathrm{~g}$

$\left[\mathrm{H}_{5} \mathrm{LFe}_{2}(\mathrm{II})\left(\mathrm{SO}_{4}\right)_{2} \cdot \mathrm{H}_{2} \mathrm{O}\right]$ Complex as a catalyst

The catalytic decomposition of $\mathrm{H}_{2} \mathrm{O}_{2}$ in presence of $\left[\mathrm{H}_{5} \mathrm{LFe}_{2}(\mathrm{II})\left(\mathrm{SO}_{4}\right)_{2} \cdot \mathrm{H}_{2} \mathrm{O}\right]$ complex as a catalyst, depends upon the concentration of the catalyst, temperature and slowed with high concentrations of $\mathrm{H}_{2} \mathrm{O}_{2}$. The rate of the reaction is of pseudo first order with respect to the concentration of the catalyst and temperature .
(B) Mechanism of the Catalytic Decomposition of $\mathrm{H}_{2} \underline{\mathbf{O}_{2}} \underline{\text { : }}$ We suggested the reaction mechanism of decomposition of $\mathrm{H}_{2} \mathrm{O}_{2}$ by $\left[\mathrm{H}_{5} \mathrm{LFe}_{2}(\mathrm{II})\left(\mathrm{SO}_{4}\right)_{2} . \mathrm{H}_{2} \mathrm{O}\right]$ Complex as the following :

$$
\begin{array}{r}
2 \mathrm{H}_{2} \mathrm{O}_{2}=2 \mathrm{HOO}^{-}+2 \mathrm{H}^{+}(4) \\
{\left[\left(\mathrm{H}_{5} \mathrm{LFe}_{2}(\mathrm{II})\left(\mathrm{SO}_{4}\right)_{2} \cdot \mathrm{H}_{2} \mathrm{O}\right) \mathrm{Complex}^{-}+\mathrm{HOO}^{-} \rightarrow\right.} \\
{\left[\left(\mathrm{H}_{5} \mathrm{LFe}_{2}(\mathrm{II})\left(\mathrm{SO}_{4}\right)_{2} \mathrm{H}_{2} \mathrm{O}\right) \text { Complex }\left(\mathrm{HOO}^{2-}\right]^{2-}(5)\right.} \\
\left.\left[\left(\mathrm{H}_{5} \mathrm{LFe}_{2}(\mathrm{II})\left(\mathrm{SO}_{4}\right)_{2} \cdot \mathrm{H}_{2} \mathrm{O}\right) \mathrm{Complex}\right)(\mathrm{HOO})\right]^{2-} \rightarrow \\
\left.\left.\left.\mathrm{H}_{5} \mathrm{LFe}_{2}(\mathrm{I})\left(\mathrm{SO}_{4}\right)_{2} \cdot \mathrm{H}_{2} \mathrm{O}\right] \mathrm{Complex}\right)\left(\mathrm{HOO}^{\prime}\right)\right]^{-}(6) \\
\left.\left[\left(\mathrm{H}_{5} \mathrm{LFe}_{2}(\mathrm{I})\left(\mathrm{SO}_{4}\right)_{2} \cdot \mathrm{H}_{2} \mathrm{O}\right) \mathrm{Complex}_{(\mathrm{HOO}}\right)\right]^{2-}+\mathrm{HO}_{2}{ }^{-} \rightarrow \\
{\left[\left(\mathrm{H}_{5} \mathrm{LFe}_{2}(\mathrm{II})\left(\mathrm{SO}_{4}\right)_{2} \cdot \mathrm{H}_{2} \mathrm{O}\right] \mathrm{Complex}^{-}+\mathrm{O}_{2}+2 \mathrm{HO}^{-}(7)\right.} \\
2 \mathrm{H}^{+}+2 \mathrm{HO}^{-}=\mathbf{2 H}_{2} \mathrm{O}
\end{array}
$$

It is assumed that step (3) is the rate determining step of the reaction, as the reduction of $\mathrm{Fe}(\mathrm{II})$ requires geometrical changes around the metal center. This mechanism is in agreement with the suggestion for other macromolecular systems and can explain the change in rate in going to more alkaline conditions, as the dependence of the redox potential of the couple $\mathrm{HO}_{2} \cdot\left(\mathrm{O}_{2}{ }^{-}\right) / \mathrm{H}_{2} \mathrm{O}_{2}\left(\mathrm{HO}^{2-}\right)$ on $\mathrm{pH}$ is very well known. It is obvious that the oxidation of $\mathrm{H}_{2} \mathrm{O}_{2}$ to $\mathrm{HO}_{2}$ or $\mathrm{O}_{2} \cdot{ }^{-}$by $\mathrm{Fe}(\mathrm{II})$ is more favorable in more alkaline conditions. This kind of mechanism does not involve any diffusible radical species in accordance to previous proposed mechanism, but several very rapid intermediate step between (3) and (4) may exist which include the participation of radicals.

Complexes of $\mathrm{Fe}(\mathrm{II})$ especially with various ligands acting as catalysts have been investigated in depth and disagreements over mechanistic details, involving intermediate radicals or complexes, have lasted for decades. The formation of iron peroxide complexes both in acidic and alkaline solutions has been confirmed and a mechanism not involving any radicals has been suggested. The difference in reactivity of $\mathrm{Fe}(\mathrm{II})$ complexes towards $\mathrm{H}_{2} \mathrm{O}_{2}$ is due to the change in the redox potential of $\mathrm{Fe}(\mathrm{II})$ ions as a result of ligation with different ligands. It was supposed that a superoxide iron (I) complex $\left[\mathrm{HO}_{2}-\mathrm{Fe}(\mathrm{I})(\right.$ Ligand) $]$ is formed from the complex $\left[\mathrm{HO}_{2}-\mathrm{Fe}(\mathrm{II})(\mathrm{Ligand})\right]$ in which an instantaneous electron transfer occurs.

The plot of $\log (d x / d t) /(a-x)^{2}$ against $(t)$, must be a straight line with slopes equal to $k / 2.303$ and intercept equal to $-\log$ $a / k_{o}$. The autocatalytic first order plots derived from the following equation (16) are illustrated in Fig.(4,5 and 6) and evaluated.

$\log (d x / d t) /(a-x)^{2}=k t / 2.303-\log a / k_{o}(9)$

The specific reaction rate $(k)$ were evaluated from the plot of $\left(\mathrm{Ln}\left[\mathrm{H}_{2} \mathrm{O}_{2}\right]_{\mathrm{dec}}\right)$ against time $(t)$ as shown in , Table (1), where

$\left[\mathrm{H}_{2} \mathrm{O}_{2}\right]_{\text {dec }}=\left[\mathrm{H}_{2} \mathrm{O}_{2}\right]_{0}-\left[\mathrm{H}_{2} \mathrm{O}_{2}\right]_{\text {unreact }}$

$\left[\mathrm{H}_{2} \mathrm{O}_{2}\right]_{\text {dec }}$ : concentration of $\mathrm{H}_{2} \mathrm{O}_{2}$ decom-position at time $t$

$\left[\mathrm{H}_{2} \mathrm{O}_{2}\right]_{0}$ : initial concentration of $\mathrm{H}_{2} \mathrm{O}_{2}$

$\left[\mathrm{H}_{2} \mathrm{O}_{2}\right]_{\text {unreact }}$ : concentration of remaining $\mathrm{H}_{2} \mathrm{O}_{2}$

\section{Conclusion}

The catalytic decomposition of $\mathrm{H}_{2} \mathrm{O}_{2}\left[\mathrm{H}_{5} \mathrm{LFe}_{2}(\mathrm{II})\left(\mathrm{SO}_{4}\right)_{2} \cdot \mathrm{H}_{2} \mathrm{O}\right]$ complex depends upon the concentration of the catalyst temperature and slowed with high concentration of $\mathrm{H}_{2} \mathrm{O}_{2}$. 


\section{International Journal of Science and Research (IJSR) \\ ISSN (Online): 2319-7064 \\ Index Copernicus Value (2015): 78.96 | Impact Factor (2015): 6.391}

The rate of the reaction is of pseudo first order with respect to the $\mathrm{Fe}(\mathrm{II})$ to $\mathrm{Fe}(\mathrm{I})$, during the slow rate determining step.

\section{References}

[1] E,Linley,S.P.Danger, G.McDonnell,C.Simons and J.Mailard;"Use of hydrogen peroxide as a biocide: new consideration of its mechanisms of biocidal action", J.of Anti. Chem 24, pp.1-8. 2012.

[2] M. A. Wassel, A.S.El.Table, M.A.Wahba and M.M.Arafa ;"Kinetic Study of The Catalytic Decomposition of Hydrogen Peroxide Over [Cu(II)Fulvate] Complex As a Catalyst" ,J.of chem.and chem. Sci 5(11), pp. 629-638. 2015.

[3] M.A.Wassel, F.I.zidan and M.El.Wardani."Effect of the composition of $\mathrm{Fe}_{2} \mathrm{O}_{3}-\mathrm{MoO}_{3}$ catalysts on the decomposition of $\mathrm{H}_{2} \mathrm{O}_{2}$ ", J.seib. chem. Soc 54 (8), pp. 425-433.1989.

[4] M.A.Wassel, F.I.zidan and M.El.Wardani, “decomposition of $\mathrm{H}_{2} \mathrm{O}_{2}$ on $\mathrm{Fe}_{2} \mathrm{O}_{3}-\mathrm{MoO}_{3}$ (2:4)and the effect of the amount of catalys and temperature on the induction period", Rassegna chimica N.4.Luglio. Agosto.1990.

[5] L.Micoli and M.Turco;"Decomposition of $\mathrm{H}_{2} \mathrm{O}_{2}$ on Monolithic Mnox/zro 2 Catalysts for Aerospace", Application Chem.Eng.Tran 43, pp.1819-1824.2015.

[6] H.E. Hamshary, M.H.El.Newehy and S.S.AlDeyab;"Oxidation of phenol by hydrogen peroxide catalyzed by metal-containing poly (amidoxime) grafted starch", Mole 16, pp. 9900-9911. 2011.

[7] J.De laat, Y.H.Dao,N.H. Elnajjar and C.Daou;"Effect of some parameters on the rate of the catalyzed decomposition of hydrogen peroxide byiron(III)nitrilotriacetate in water", water research 45, pp. 5654 5664.2011.

[8] O. Zeineb ,B. A. Hedi, M. R. Jeday,C. Cheker ;"Kinetic study of the catalytic decom-positionof $\mathrm{H}_{2} \mathrm{O}_{2}$ in phosphoric acid medium", Int. J. o f. hydrogen energy 40, pp. 1278-1282.2015.

[9] M. Fouda, M. Abd-Elzaher, M. Shakdofa, F. El Saied, M. Ayad, A. S. El Tabl ;"Synthesis and characterization of transition metal complexes of $N^{\prime}$ [(1,5-dimethyl-3-oxo-2-phenyl-2,3-dihydro-1Hpyrazol-4-yl)methylene]thiophene-2-carbohydrazide", Tran. Met. Chem. 33, pp. 219-228. 2008.

Volume 6 Issue 7, July 2017 www.ijsr.net 